ks. Robert Tyrała

\title{
SŁUŻBA PRAWDZIE, POSŁUGA MYŚLENIA I WRAŻLIWOŚĆ ETYCZNA - WYZWANIA DLA UNIWERSYTETÓW WEDEUG JANA PAWŁA II
}

W 1997 roku podczas szóstej pielgrzymki papież Jan Paweł II kanonizował św. Królową Jadwigę, a w kolegiacie św. Anny miało miejsce spotkanie ze światem nauki z okazji 600-lecia Wydziału Teologicznego Uniwersytetu Jagiellońskiego. Papież spotkał się z profesorami i studentami w dniu 8 czerwca 1997 roku ${ }^{1}$. Stąd też zrodziło się papieskie przesłanie do uniwersytetów... a więc także do Akademii Muzycznej w Krakowie!

\section{Alma Mater}

Bardzo ważną kwestią w przemówieniu papieża było zwrócenie uwagi na Uniwersytet jako matkę Alma Mater. Matka to ta, która rodzi i wychowuje, która się troszczy, a Uniwersytet w tym właśnie jest do niej podobny.

Ta troska jest natury duchowej: rodzenie dusz do wiedzy, do mądrości, kształtowanie umysłów i serc. Jest to wkład z niczym nie porównany ${ }^{2}$.

Uczelnia jest domem dla profesorów i studentów, a w domu człowiek czuje się bezpiecznie. Uczelnia jest matką, która wychowuje. Wychowanie to ma być zawsze ukierunkowane w stronę dobra i musi pozostawać wrażliwe na potrzeby najbiedniejszego. Uczelnia ma się więc troszczyć o każdego i każdy ma się w niej czuć dobrze, spełniony i bezpieczny.

${ }^{1}$ Zob. Jan Paweł II, Przemówienie wygłoszone z okazji sześćsetlecia Wydziału Teologicznego Uniwersytetu Jagiellońskiego, Kraków 8 czerwca 1997, Pielgrzymki do Ojczyzny 1979-1983-19871991-1995-1997-1999-2002, Przemówienia, homilie, Kraków 2005, s. 983-990.

2 Jan Paweł II, Przemówienie wygłoszone z okazji sześćsetlecia Wydziału Teologicznego, dz. cyt., s. 986. 


\section{Służba prawdzie}

Papież Jan Paweł II przypomniał tė̇, że uniwersytet powołany jest do służby prawdzie, jej odkrywania i przekazywania innym. Stwierdzał wówczas:

człowiek przekracza granice poszczególnych dyscyplin wiedzy, tak aby ukierunkować je ku owej prawdzie i ku ostatecznemu spełnieniu swego człowieczeństwa. Można tu mówić o solidarności różnych nauk w służbie człowiekowi i w odkrywaniu coraz pełniejszej prawdy o nim samym i o otaczającym go świecie, kosmosie. (...) poznanie prawdy rodzi jedyną w swym rodzaju duchową radość 3 .

Bardzo ważne w wystąpieniu papieża były słowa mające dodać odwagi i nadziei wysiłkom uczonych w ich drodze dalszego poszukiwania prawdy. Papież mówił:

jeżeli dzisiaj, jako papież, jestem tutaj z wami - ludźmi nauki - to po to, aby wam powiedzieć, że człowiek współczesny was potrzebuje. Potrzebuje waszej naukowej dociekliwości, waszej wnikliwości w stawianiu pytań i uczciwości w szukaniu na nie odpowiedzi. Potrzebuje tej swoistej transcendencji, jaka jest właściwa uniwersytetom. Poszukiwanie prawdy, nawet wówczas, gdy dotyczy ograniczonej rzeczywistości świata czy człowieka, nigdy się nie kończy, zawsze odsyła ku czemuś, co jest ponad bezpośrednim przedmiotem badań, ku pytaniom otwierającym dostęp do Tajemnicy. Jakże ważne jest, by ludzka myśl nie zamykała się na rzeczywistość Tajemnicy, by człowiekowi nie brakowało wrażliwości na Tajemnicę, by nie brakowało mu odwagi pójścia w głąb

Posługa prawdy wymaga więc dyskusji, poszukiwania, wrażliwości i otwarcia na nią. Nie da się inaczej zrozumieć roli i zadania wyższej uczelni jak właśnie w kontekście poszukiwania prawdy. To dotyczy także prawdy o muzyce i jej przesłania.

\section{Posługa myślenia}

Kolejnym nadal aktualnym aspektem przesłania papieża Jana Pawła II do uniwersytetów jest kwestia posługi myślenia.

3 Jan Paweł II, Przemówienie wygłoszone z okazji sześćsetlecia Wydziału Teologicznego, dz. cyt., s. 986.

${ }_{4}$ Jan Paweł II, Przemówienie wygłoszone z okazji sześćsetlecia Wydziału Teologicznego, dz. cyt., s. 987. 
Każdy intelektualista, bez względu na przekonania, jest powołany do tego, by kierując się tym wzniosłym i trudnym ideałem, spełniał funkcję sumienia krytycznego wobec tego wszystkiego, co człowieczeństwu zagraża lub co go pomniejsza. Być pracownikiem nauki, to zobowiązuje! Zobowiązuje przede wszystkim do szczególnej troski o rozwój własnego człowieczeństwa ${ }^{5}$.

Nie da się inaczej myśleć o pracownikach nauki jak o tych, którzy twórczo towarzyszą swoim podopiecznym. To ma być prawdziwa relacja na poziomie głębokiej myśli. Niezależnie od reprezentowanego światopoglądu myślenie zawsze ma przyszłość. Tu chodzi o autentyczną relację uczeń-mistrz.

\section{Wrażliwość etyczna}

Papież Jan Paweł II w swoim wystąpieniu do świata nauki w 1997 roku zwrócił uwagę na to, że

w codziennym trudzie pracownika nauki konieczna jest także szczególna wrażliwość etyczna. (...) Czynności umysłu muszą być koniecznie włączone w duchowy klimat niezbędnych cnót moralnych, jak szczerość, odwaga, pokora, uczciwość oraz autentyczna troska o człowieka. Dzięki wrażliwości moralnej zachowana zostaje bardzo istotna dla nauki więź pomiędzy prawdą a dobrem. Tych dwóch spraw nie można bowiem od siebie oddzielać! Zasady wolności badań naukowych nie wolno oddzielać od odpowiedzialności etycznej każdego uczonego. W przypadku ludzi nauki ta odpowiedzialność etyczna jest szczególnie ważna. Relatywizm etyczny oraz podstawy czysto utylitarne stanowią zagrożenie nie tylko dla nauki, ale wprost dla człowieka i dla społeczeństwa ${ }^{6}$.

Owa wrażliwość etyczna stanowi fundament rozwoju nauki i sztuki. Szczerość, pokora, odwaga, uczciwość, troska o człowieka mają towarzyszyć wszelkim działaniom na uczelni. Ich brak byłby zagrożeniem dla przyszłości i każdego człowieka, każdego studenta, ale także samego naukowca czy artysty.

${ }_{5}$ Jan Paweł II, Przemówienie wygłoszone z okazji sześćsetlecia Wydziału Teologicznego, dz. cyt., s. 987.

6 Jan Paweł II, Przemówienie wygłoszone z okazji sześćsetlecia Wydziału Teologicznego, dz. cyt., s. 988. 


\section{Integralna koncepcja osoby ludzkiej}

Bardzo istotnym elementem zdrowego rozwoju nauki jest według papieża Jana Pawła II integralna koncepcja osoby ludzkiej. W kontekście rozwoju nauki i rozmaitych badań, także badań genetycznych ważne pozostaje w tym kontekście wielkie zadanie postawione przez papieża przed uniwersytetami:

formowanie ludzi nie tylko kompetentnych w swojej specjalizacji, czasem wąskiej, bogatych w encyklopedyczna wiedzę, ale nade wszystko w autentyczną mądrość. Tylko tak uformowani, będą oni mogli wziąć na swe barki odpowiedzialność za przyszłość Polski, Europy i świata 7 .

Ludzie mądrzy są dzisiaj niezwykle potrzebni nie tylko światu, ale także Polsce i Kościołowi. Całościowe - integralne - formowanie człowieka temu właśnie celowi służy. Gdy kształtuje się wspaniałego artystę, to nie chodzi tylko o to, by doskonale zagrał na instrumencie, ale nade wszystko o to, by w mądrości życiowej umiał odnaleźć się w każdej sytuacji.

\section{Kościół jest zawsze z Wami}

Niezwykle też ważne było potwierdzenie przez papieża wyrażonego już wcześniej przekonania że Kościołowi zależy na ścisłej relacji ze światem nauki, którą uważa za ważną i potrzebną:

Bardzo pragnąłem tego spotkania, aby raz jeszcze zaświadczyć, iż Kościołowi sprawy nauki nie są obojętne. Chciałbym, abyście Państwo zawsze byli pewni tego, iż Kościół jest $\mathrm{z}$ wami i - zgodnie ze swym posłannictwem - pragnie wam służyć (...) zwracam się do czcigodnych jubilatów: do mojego Uniwersytetu Jagiellońskiego i do Papieskiej Akademii Teologicznej, z najlepszymi życzeniami wszelkiej obfitości darów Ducha Świętego na dalszą drogę służby prawdzie ${ }^{8}$.

Dialog pomiędzy Kościołem, a światem nauki jest nie tylko niezwykle istotny, ale wręcz konieczny. Jest potrzebny dla przyszłości świata i Ojczyzny. Dialog taki opierać się powinien na prawdzie i zawsze ma być służbą. Inaczej zdradzimy

7 Jan Paweł II, Przemówienie wygłoszone z okazji sześćsetlecia Wydziału Teologicznego, dz. cyt., s. 988-889.

8 Jan Paweł II, Przemówienie wygłoszone z okazji sześćsetlecia Wydziału Teologicznego, dz. cyt., s. 989. 
bardzo ważną rzeczywistość, zdradzimy tożsamość wynikająca z wiary. Kościół jest drogą człowieka, każdego człowieka i nikogo nie odrzuca. Kościół zawsze jest z uczelniami, a więc z całą wspólnotą akademicką: nauczycielami akademickimi, pracownikami administracyjnymi oraz studentami.

\section{Benedykt XVI - potwierdza nauczania Jana Pawła II}

4 lipca 2015 roku w Castel Gandolfo papież emeryt Benedykt XVI odbierając doktoraty honoris causa obu naszych uczelni ${ }^{9}$ powiedział:

działalność obydwu uczelni, które przyznają mi ten doktorat honoris causa, stanowi istotny przyczynek, aby wielki dar muzyki pochodzącej z tradycji wiary chrześcijańskiej pozostawał żywy i pomagał, by twórcza siła wiary także w przyszłości nie gasła. Za to wam wszystkim serdecznie dziękuję, nie tylko za zaszczyt, jakim mnie obdarzyliście, ale także za całą pracę, jaką wykonujecie w służbie pięknu wiary. Niech Pan was wszystkich błogosławi! ${ }^{10}$

9 Akademii Muzycznej w Krakowie i Uniwersytetu Papieskiego Jana Pawła II w Krakowie.

10 Benedykt XVI, Słowa podziękowania $z$ okazji nadania tytułu doktoratu honoris causa Uniwersytetu Papieskiego Jana Pawła II w Krakowie oraz Akademii Muzycznej w Krakowie z 4 lipca 2015 roku, Archiwum Rektoratu Uniwersytetu Papieskiego Jana Pawła II w Krakowie. 


\section{Abstract \\ Serving the Truth, Service to Thinking and Ethical Sensitivity - Challenges for Universities according to John Paul II}

In 1997, during his 6th pastoral pilgrimage to Poland, John Paul II canonized Blessed Queen Hedvig. The Canonization Mass was followed by the meeting with the representatives of Polish universities to be held in St. Anne's Collegiate Church so as to mark the 600th anniversary of the Faculty of Theology of the Jagiellonian University. On $8^{\text {th }}$ June 1997 the Pope talked to JU students and professors. In his speech he made a highly significant reference to University as Alma Mater. Mother who gives birth, who educates and who takes care of her children and University is similar to the former in this respect. The above mentioned care is of spiritual nature: making souls be born for knowledge and wisdom, forming minds and hearts. It is a contribution which can never be overestimated. John Paul II reminded as well that university's mission is to serve the truth, to discover it and bequeath to others. Another, still relevant, message in Pope's address to universities is the service to thinking. In his daily work a scientist needs a particular kind of ethical sensitivity. And an integral concept of a human person is, according to John Paul II, a hugely important condition for science development.

Keywords: John Paul II, Benedict XVI, meeting with University representatives 8 June 1997, St. Ann Collegiate Church, Alma Mater, serve the truth, service to thinking, ethical sensitivity, integral concept of a human person

ks. Robert Tyrała, Stużba prawdzie, posługa myślenia i wrażliwość etyczna - wyzwania dla uniwersytetów według Jana Pawła II, [w:] Uniwersytet wobec uniwersum, red. Zofia Zarębianka, Kraków 2020, s. 75-80 (Dni Jana Pawła II).

http://dx.doi.org/10.15633/9788374389082.06 